\title{
Rainwater Harvesting Innovations for Flood-Resilient Cities
}

\author{
C. C. Abenayake, K. I. U. T. De Silva, P. K. S. Mahanama
}

\begin{abstract}
The expansion of impermeable surfaces in cities have absurdly increased the urban runoff; blocking its pathways to infiltration and evaporation. Rainwater harvesting can be considered as an effective initiative to tone-down the disruptions made to urban runoff pathways. While adopting built form-led solutions from one end to address the consequences of increased urban runoff which eventually increases the frequency and magnitude of urban flooding, rainwater harvesting solutionscan also be adopted in parallel. This study attempts to simulate runoff levelscorrespondent to different vertical-density configurations with reference to a selected micro-watershedin Colombo, Sri Lanka. Simulations were made for four hypothetical built form scenariosin which a roof rainwater harvesting system is in-built: high-rise, intermediate-rise, mid-rise and low-rise. The extent of land and the size population were constant under each scenario. As per the results revealed,low-rise built form was identified as the most disturbing to natural pathways, whereas high-rise built formwas recognized as relatively better options for built-up area expansion.
\end{abstract}

Keywords:Disaster Resilience,Urban flooding, GIS, Rainwater Harvesting, Spatial Simulation

\section{INTRODUCTION}

Rain Water Harvesting is an ancient practice of the world dated back to $2500 \mathrm{BC}$ in Indus Valley Civilization. Historically, the concept of rainwater harvesting has been popular in coping with seasonal water scarcity, particularly among semi-arid agricultural villages[1]. The global governance bodies in the modern era appreciate rainwater harvesting as a sustainable practice to overcome the challenges of incongruous ecological systems including global water stress that climaxed in the era of Anthropocene. In this milieu, rainwater harvesting is progressively acknowledged in many countries as a resilient and eco-friendly water management practice.

Rainwater harvesting at household-scale is also gaining popularity as a water conservation practice in sustainable housing and neighborhood planning professional domains. In some city councils and state level authorities, rainwater harvesting has been made mandatory by respective by-laws and statutes. Moreover, some communities practice rainwater harvesting either in the absence of an alternativereliable water supply source or due to the high cost of the alternative

Revised Manuscript Received on January 2, 2020.

* Correspondence Author

C. C. Abenayake *, Urban Simulation Lab, Department of Town and Country-Planning, University of Moratuwa, Katudedda, Sri Lanka. Email: chethika@uom.lk

K. I. U. T. De Silva, Lanka Rain Water Harvesting Forum, Sri Lanka Email: iuthithakshana@gmail.com

P. K. S. Mahanama, Department of Town and Country-Planning, University of Moratuwa, Katudedda, Sri Lanka.Email: mahanama@uom.lk water supplysources[2]. For instance, several small island communities in Asia such as Ko Panyi in Thailand, Baththalangunduwain Sri Lanka utilizeroof rainwater harvesting as the primary water supply source for domestic purposes in absence of an alternative. Further, urban poor living in South Asian megacities such as Dhaka, Delhi and Karachiare increasingly approaching rainwater harvesting as an affordable water source. In overall, the importance of rainwater harvesting as a resilient and eco-friendly water conservation practice has been admitted globally at different scales.

World today is urbanizing at an accelerated rate producingservice and manufacturing centered economies along with high-density urban agglomerations. Urban agglomerations are typically considered as economic hubs that generate wealth, ideas and access to high level of services. This trendled the rural to urban in-migration worldwide creating over thirty megacities making half of the world population liveson two percent of the earth's land. The unprecedented rise of urban areas in the world brought-up an immense pressure upon the urban environmental systems that contest the ecological thresholds, carrying capacities and limits to growth[3]. Urban flooding is one of those adversities caused by extensive urban expansion and exacerbated by climate change[4].

Rainwater harvesting has recently been recognized as an urban flood management strategy considering its role in water retention during high-intensityprecipitation events. Sustainable Urban Drainage Systems (SUDS), Green Infrast ructure (GI), LowImpact Development(LID) and Water Sensitive Urban Design (WSUD) are some key concepts in which rainwater harvestingis promoted in controlling urban flooding[5]. LID,being a concept in promoting the inherent equilibrium of the hydro pathways, appreciates rainwater harvesting as a complementary measurein reducing the frequency of occurrence, peak flows and volumes of urban surface runoff [1]. Theexcess of harvested rain water can be injected to be infiltrated for enriching theaquifers[6].

Several studies have highlighted the effectiveness of rainwater harvesting as a strategy in mitigating urban flood risksat watershed scale [7];[8];[9];[10]. The flood height and the lag time can have a direct relationship with the impervious coverageat watershed scale. Urbanization has expanded built-up areas increasing the urban imperviousness causing high surface runoff.Built-up areas are impervious surfaces that reduce the infiltration and increase the surface runoff.

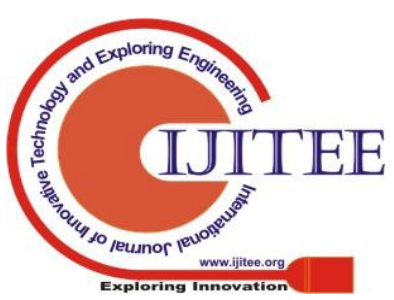


Hence, the imperviousness of urban built form is a decisive factor in determining the magnitude of urban flooding. Roof rainwater harvesting can break this vicious feedback loop by retaining the precipitated water up until a given planned time of release. Roof rainwater harvesting systems are mostly designed considering the water demand, therefore,thosemight not be practical to be developed with the full capacity to store the fullvolume of water precipitated rather those may be effectively designed to reduce the peak flows and lag time. In such systems, the rain water will be stored during peak rainfall (i.e., high intensity) and discharge whenever the lag time is over.

Many countries have incorporated roof rainwater harvesting into building regulations, codes, guidelines or best practices. In several countries, roofrainwater harvesting has been made mandatory for buildings. For instance, in Sri Lanka,it is mandatory to have a rainwater harvesting unit in all buildings erected in urban areas. Nevertheless, there are very limited studies being carried out to analyze the effect of the different types of built form in reducing urban flooding through roof rainwater harvesting systems. Hu et.al.'s works on urban flood management at watershed levelhave assessed the effectiveness of Low impact development (LID) under different density scenarios: high density, low density and garden [7];[11];[3]. Results revealed that the high density built form mostly triggers urban flooding in compared to low density built forms and gardens. The high density may take different forms depends on the configuration and the composition of buildings. As the built form is diverse, its impact on urban runoffmay also differs. Nevertheless, as per the knowledge gathered through literature, there were very limited studies to address the effectiveness of rain water harvesting solutions in-built to different built form configuration in responding to urban flooding. Hence, this study is attempted to simulate and evaluate the effectiveness of high-density development with different heights in controlling urban runoff through roof rainwater harvesting at watershed scale.

The second section of this paper describes the method adopted and materials utilized in the process of runoff simulation under hypothetical vertical density scenarios. The third section reveals the results of the simulated models. Then compares the effectiveness of low-rise, medium-rise, intermediate-rise and high-rise building scenarios in mitigating urban flooding. The fourth section concludes the discussion with recommendations for the future development of high density built forms.

\section{METHODS AND MATERIALS}

The key objective of the study is to assess the diversityof vertical density among high density built forms in account of the effectiveness ofurban runoff management by means of roof rain water harvesting in a selected urban watershed, particularly in Colombo, Sri Lanka.

\section{A. Selection of the Study Area}

Colombo is the commercial capital of Sri Lanka. Out of the 20 million population in the country, 15 percent lives within Colombo district. When referring to the district-wise (i.e., Sri Lanka consist of 25 administrative districts) population census data publishedby the Census and Statistics Department of Sri Lanka, Colombo district has the highest urbanization rate (i.e., over 50 percent urban). As per the land use data published by the Survey Department of Sri Lanka, 80 percent of agricultural lands in Colombo district has been converted into non-agricultural uses during the last three decades. The continuous and vast expansion of built-up areas in the district has caused to reduce infiltration of precipitated water making most of the wells dried-up or salinized. In the year 2018, Colombo was declared as the first and only wetland capital city of the world under Ramsar Wetland City Accreditation. Colombo consisted of a well-connected low-lying area network including the abandoned and cultivating paddy fields, swamps and coastal marshes. Wetlands play an effective role in water retention and detention which absorbs the precipitated water quickly and releases gradually. The wetland networkperforms as a natural flood defense mechanism yet the intensive built-up area expansion in the city as well as in the upper watersheds has already exceeded the flood assimilative capacity of Colombo making it is subjected to flash floods, riverine floods and coastal floods[12]. For instance, during the torrential rain event that occurred in May 2016, over 30 percent of the population in the Colombo district has been affected Considering the given circumstances, Colombo was selected as a versatile enough study area for the purpose of this study.

Colombo district consists of 5 municipal councils. Out of them, Colombo Municipal Council (CMC) has the highest net building density, therefore,it was assumed as the area with the lowest previous surface coverage. Hence, the study area was further narrowed-down to CMC area. For the purpose of urban runoff simulation, micro watersheds were technically recognized as feasible units of observation. Hence, the study performed micro watershed delineation in aGIS-based (Geographic Information System) platform where more details are provided in the next section of this paper (refer section II. B). By means of the watershed delineation, 6 watersheds were plotted (Fig. 2).

Next, the data on flood-affected population as a percentage of the total population was obtained ward-wise (i.e., CMC is zoned into 42 wards for the local administration purpose) with reference to the flood evacuation data released by the Disaster Management Centre, Sri Lanka in 2017 (Fig. 1). The delineated 6 micro watersheds were numbered an overlapped on flood-affected population data map (Fig. 1).

Considering the number of flood-affected population, a micro watershed of 3.5 square kilometers was selected for urban simulation (please refer micro watershed number 2 in Fig. 1). 


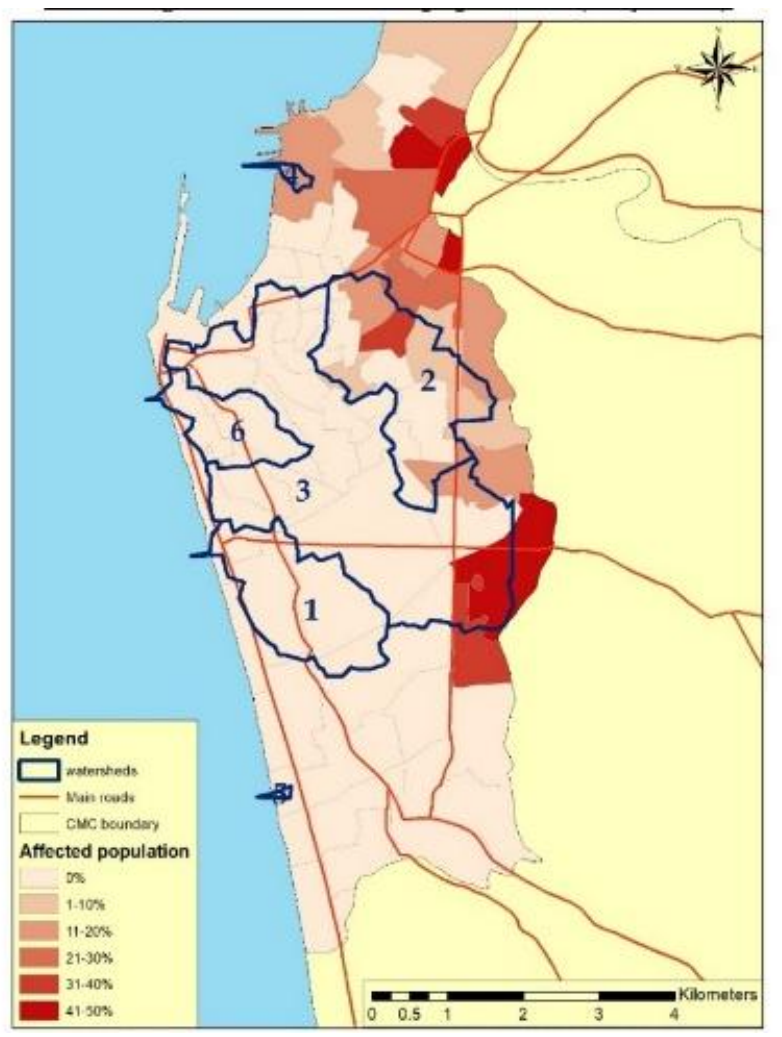

Fig. 1: Ward-wise flood (May 2016) affected population as percentage of total population

\section{B. Delineation of micro-watersheds in CMC area}

The micro watershed delineation process was carried out on a GIS-based platform[13]. The first step of the watershed delineation process is the preparation of a digital elevation model (DEM) based on the drainage and slope. As Colombo is a coastal flat terrain, the difference in elevation was limited to a range from 0-40meters. The surveyed contour data of the $\mathrm{CMC}$ area is also limited to $10 \mathrm{~m}$ intervals, hence, unable to reveal the variations of micro watersheds. Therefore, the study utilized two open-access satellite image processing tools to compute slope: i) Google Earth elevation data and ii) USGS (United States Geological Survey agency) 3DEP (3D Elevation Programme) DEM. Google Earth elevation data typically reveals an accuracy upto 2.5 meters[14] and 3DEP DEM has also met the National Standard for Spatial Data Accuracy (NSSDA), i.e.,3.04 meters, the standard at 95 percent confidence level[15].

USGS 3DEP DEM was downloaded from the USGS earth explorer with elevation data.Conversion of Google Erath elevation data into the GIS platform was performed by employing TCX converter 2.0.32 version which is a freely downloadable GPS (Geographic Positioning System) data converter. In preparation of the DEM, rivers and streams which are connected to upper watersheds beyond the boundaries of CMC were manually excluded as the study is focused only on urban flooding.

Considering the degree of detail produced through the micro-watershed delineation process, USGS 3DEP DEM was opted for delineating the micro watershed(Fig. 2).

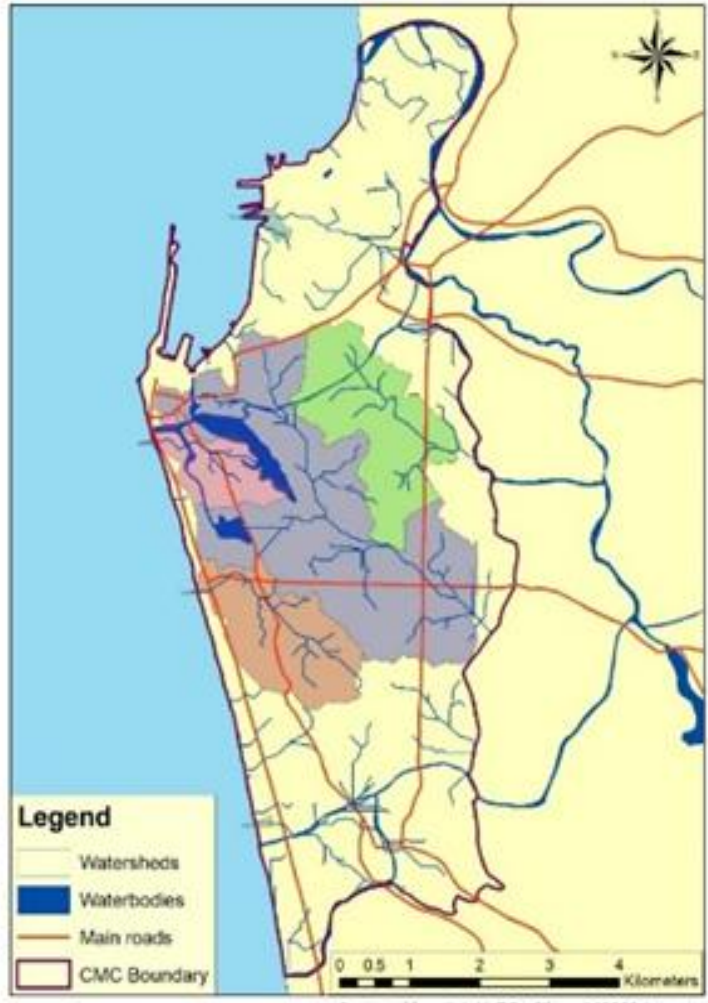

Fig. 2: Watershed delineation of $\mathrm{CMC}$ area

\section{Modeling urban runoffin the selected micro-watershed}

There are several hydrodynamic rainfall-runoff simulation tools available to simulate flood heights and lag time variations at micro-watershed level. This study employed the Storm Water Management Model (SWMM) which is developed by the Environmental Protection Agency, United States (US/EPA) for runoff modeling. SWMM is free and open-source software that has already been verified at a reasonable accuracy as per several studies and offers high credibility for real-world applications[16]. The latest version of SWMM (SWMM 5.1) is inbuilt with eight LID functions including rainwater harvesting[17].

SWMM is a developed version of rational formula which is directed by the momentum and conservation of mass (Eq 1).

$$
\frac{\partial Q}{\partial t}+g A S_{f}-2 V \frac{\partial A}{\partial t}-V^{2} \frac{\partial A}{\partial x}+g A \frac{\partial H}{\partial x}=O(1)
$$

Wherein;

A $=$ Cross-sectional area of the flow,

$\mathrm{H}=$ Hydraulic head,

$\mathrm{S}_{\mathrm{f}}=$ Friction slope,

$\mathrm{Q}=$ Discharge through the conduit,

$\mathrm{V}=$ Velocity in the conduit.

For the purpose this study, input data for the model were impervious coverage of the cross sectional area of the flow,infiltration rate by soil type, rainfall intensity and the capacity of drainage. All of the input datawere obtained by secondary sources. Data pertaining to the Velocity in the conduit and Hydraulic head including the details of outlets, manholes and conduits were collected from the National

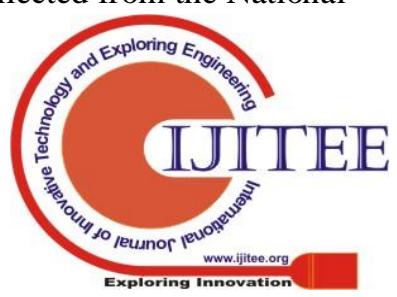


Water Supply and Drainage Board,Colombo (NWSDB). The selected micro-watershed was considered as the cross-sectional area of the flowand zoned into sub-catchments $(n=629)$ considering the slope and clusters of drainage. Average daily rainfall data for 16 consecutive days pertaining to the flood event that occurred in May 2016 wereobtained from Rathmalana meteorological observatory, Sri Lanka. The peak rainfall $(190.8 \mathrm{~mm})$ was recorded on the 15th of May 2016.

Due to the limited access to data, there were several assumptions made in the process of runoff modeling as follows:

a. A uniform soil type is present across the cross-sectional area of the flow. Therefore, Manning's coefficient(i.e., ' $n$ ') of all sub catchments is aconstant.

b. A uniform rainfall was received across the cross-sectional area of the flow during the given event. Rainfall intensity was also assumed as equal throughout the day.

c. The effects of canals which pass-through two or more micro watersheds were manually excluded in order to keep the simulation free from the effect of riverine floods.

d. Except for roads and building plinth area, the rest of the cross-sectional area of the flow is pervious. The degree of perviousness was determined based on the land use type (i.e., residential outdoor 80 percent, commercial outdoor 25 percent, industrial outdoor 50 percent, parks $\&$ playgrounds 100 percent).

\section{Simulation of hypothetical built forms scenarios}

The modeled runoff (Fig.4) was simulated with four hypothetical built form scenarios with in-built roof rainwater harvesting systems of different vertical density.

The diversity of vertical density was derived from the maximum permissible building height regulation for CMC as stipulated in the urban development plan. Four types of vertical densities were considered as low rise ( $<4$ floors), inter-mediate rise ( 5 to 8 floors), mid-rise ( 9 to 12 floors) and high-rise (>13 floors). Along with the height, the plot coverage regulation is also varying as 66 percent for low riseand 50 percent for the other types.

The hypothetical building density scenarios were based on two assumptions as follows:

a. The total population within the micro watershed remains constant (as same as the existing population) regardless of the built form. The total population of the watershed $(84,203 \approx 80,000)$ was also calculated based on uniform distribution assumptions because population cell data was not exactly fitting to the watershed boundary. Household size was assumed as 5 and the number of dwelling units as 16,000. The average size of a dwelling unit per person as 300 square meters.

b. The percentage of roads under low-rise and intermediate-rise scenarios was assumed as 10 percent from the aggregated building plinth area whereas the same in the mid-rise and high rise scenarios wereassumed as same as the existing percentage $(<10$ percent).

Computation of roof rainwater harvesting capacity

under each hypothetical scenario was based on the method indicated in Sri Lankan regulations published by the Gazette Notification No: 1597/8 of 2019 (Fig. 4).

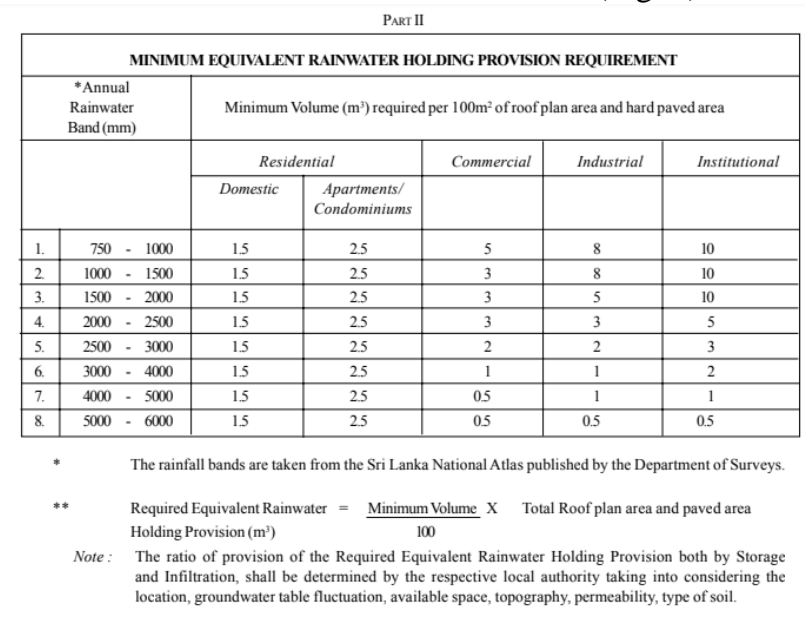

Fig. 3: Rainwater harvesting capacity standards

Accordingly, urban runoff under four hypothetical built-up scenarios was simulated and the result has been revealed in the next section.

\section{RESULTS AND DISCUSSION}

\section{A. Urban runoff simulations under alternative vertical density scenarios of high-density built form}

The resultswere compared to identify which development scenario is the most effective in accommodating roof rainwater harvesting systems as a measure of reducingurban runoff.

Fig. 4 depicts the surface runoff modeled based on the existing built-up area under no rainwater harvesting in-built scenario.

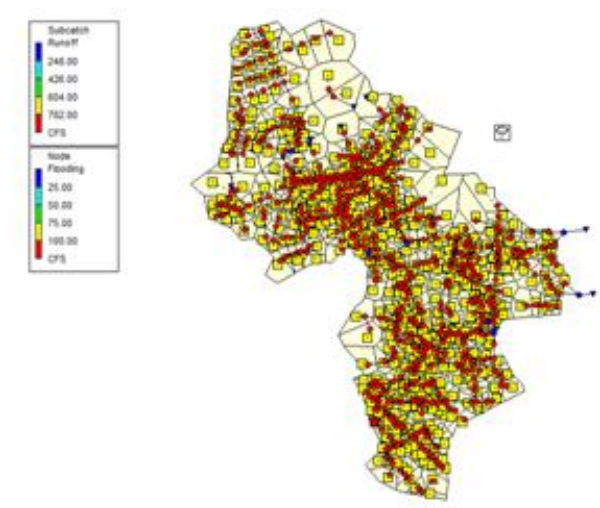

Fig. 4: Storm water runoff under the existing situation

As per the results, over 95 percent of sub-catchments are flood-prone under the present situation.

Fig. 5depicts the difference made when roof rainwater harvesting system is in-built in all buildings in the watershed. As per the results, 99 percent of the sub-catchments become flood-free even during extreme rainfall conditions if rainwater harvesting is fully introduced. 

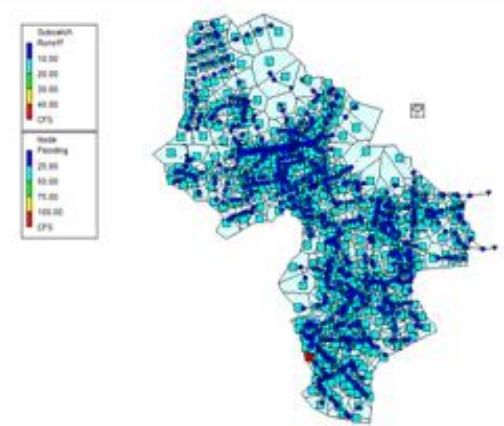

Fig. 5: Sufrace runoff of existing built area along with rainwater harvesting in-built

Existing development in the watershed is inter-mediate-rise in average. Nevertheless, it is a good mixture of different vertical densities, where the relative effect of vertical density variation cannot be distinguished. Hence, four hypothetical vertical density scenarios were developed assuming only one type of building height is present in the watershed at a given time. Accordingly, Fig6,7, 8 and 9 depict the urban runoff under low-rise, intermediate-rise, mid-rise and high-rise built form respectively assuming rainwater harvesting is in-built in each building.
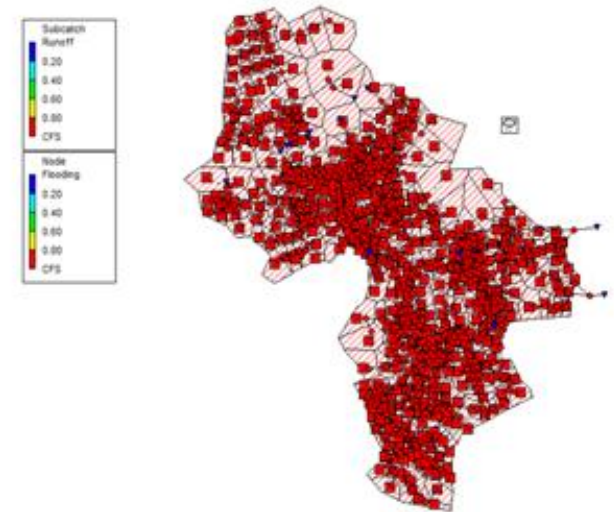

Fig. 6: Low-rise development
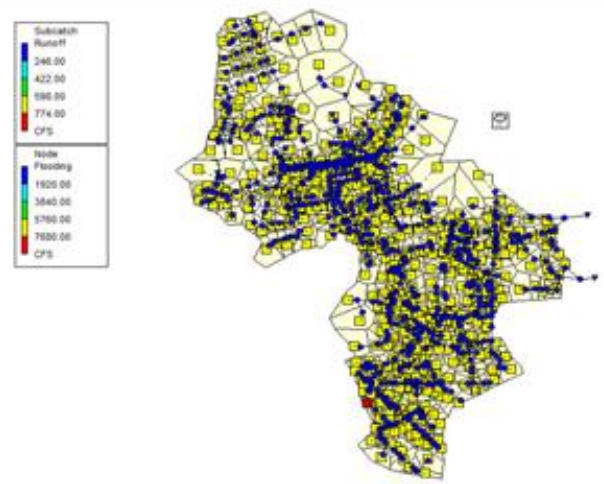

Fig. 7: Inter mediate-rise development
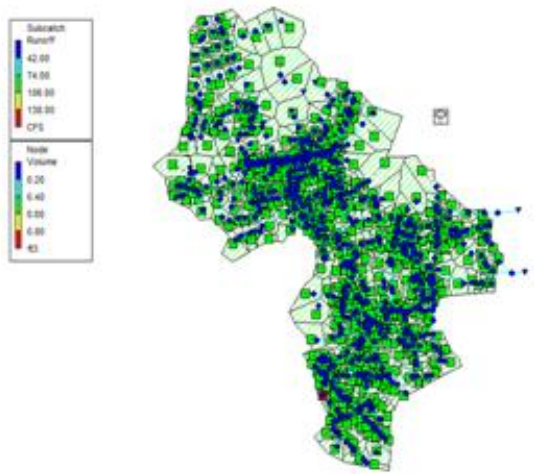

Fig. 8: Mid-rise development
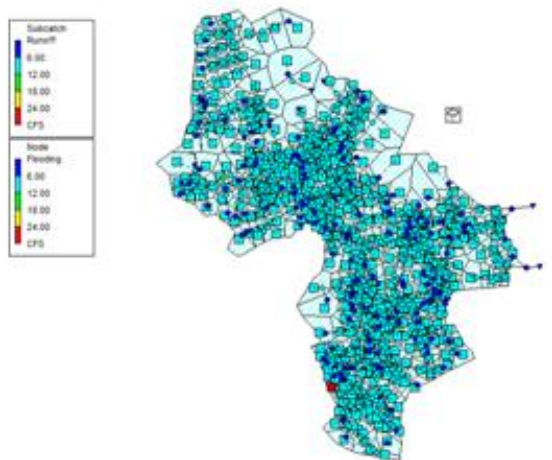

Fig. 9: High-rise development

Under the low-rise development scenario, over 80 percent of sub-catchments are flood-prone whereas in three other scenarios (i.e., intermediate-rise, mid-rise and high-rise) over 99 percent of the sub-catchments are flood-free. In all four scenarios, rainwater harvesting is in-built but its effectiveness is not significant under the low-density scenario. Even though the intermediate-rise is flood-free at the given rainfall intensity, it indicates that the stormwater drains are at a saturated (full capacity operation) level. Hence, mid-rise and high-rise show better efficiency in urban runoff.

\section{CONCLUSION}

Rainwater harvesting can be considered as an effective solution in harmonizing urban runoff, thereby, reducing the occurrence of flash floods. Low-rise high density consists ofa high building plinth area which provide more roof surface to harvest rain water. High-rise high density consists of relatively a less building plinth area but more open spaces for infiltration. Hence, in which built-form is the roof rain water harvesting system is more effective? The study was conducted to answer this question, which is unresolved in the current practice in Sri Lanka.

Results revealed a variance in the effectiveness of rainwater harvesting for urban runoff control underdifferent built form configurations. The simulation was madewith reference to four hypothetical scenarios, where a given population wasallocated in alternative high-density built form configurations; high-rise, mid-rise, intermediate-rise and low-rise. 
When the building height decreases, the urban runoff increases revealing an inverse relationship. Even if the volume of roof rainwater yieldincreases when the plinth area increases, the plot coverage is higher under low-rise built form. This reduces the infiltration and increases the surface runoff.

The results were revealed with certain assumptions and it limits the strength of the argument. Hence, future research is worth to be focused on reducing the assumptions making simulationsmore realistic. Further, the modeling can be coupled with several LID options and check their effectiveness at different building densities.

Considering the findings, the high-rise built forms can be considered as more effective in addressing urban flooding along with roof rainwater harvesting systems in-built. The findings will be useful for decision-makers on built-form in making cities more resilient to urban flooding.

\section{ACKNOWLEDGMENT}

Publication of this research article was supported bythe Senate Research Committee (SRC) Conference \& Publishing Support Grant University of Moratuwa, Sri Lanka.

\section{REFERENCES}

1. A. Campisano, D. Butler, S. Ward, M. Burns, E. Friedler, K. DeBusk, A. Rahman, H. Furumai, M. Han and N. Lloyd, "Urban rainwater harvesting systems: research, implementation and future perspectives," 2017, Water Research, pp. 195-209.

2. A. GhaffarianHoseini, J. Tookey, S. Yusoff and N. Hassan, "State of the art of rainwater harvesting systems towards promoting green built environments: a review," Desalination and Water Treatment, 2016, pp. 95-104.

3. C. Abenayake, Y. Mikami, Y. Matsuda and A. Jayasinghe, "Ecosystem services-based composite indicator for assessing community resilience to floods," Environmental Development,2018, vol. 27, pp. 36-46.

4. E. S. Ranjan and C. Abenayake, "A study on community's perception on disaster resilience concept," Procedia Economics and Finance, 2014, vol. 18, pp. 88-94.

5. T. L. Moorw, C. M. Rodak, J. R. Vogel and F. Ahmed, "Urban stormwater characterization, control and treatment," Water Environment Research, 2018, pp. 1821-1871.

6. P. Dillon, "Future management of aquifer recharge," Hydrogeology, 2005, pp. 313-316.

7. M. Hu, T. Sayama, X. Zhang, K. Tanaka, K. Takara and H. Yang, "Evaluation of lowimpact development approach for mitigating flood inundation at a watershed scale in China," Journal of Environmental Management, 2017, pp. 430-438.

8. H. Qin, Z. Li and G. Fu, "The effects of low impact development on urban flooding under different rainfall characteristics," Jornal of Environmental Management, 2013, pp. 577-585.

9. A. Palla and I. Gnecco, "Hydrologic modeling of Low Impact Development systems at the urban catchment scale," Journal of Hydrology,2015, pp. 361-368.

10. X. Zhang, X. Guo and M. Hu, "Hydrological effect of typical low impact development approaches in a residential district," Natural Hazards, 2015, pp. 389-400.

11. C. Mei, J. Liu, H. Wang, W. Shao, L. Xia, C. Xiang and J. Zhou, "Modelling the ability of source control measures to reduce inundatin risk in a community-scale urban drainage system," International Association of Hydrological Sciences, 2018, pp. 223-229.

12. C. Abenayake, Y. M, A. Marasinghe and Y. Takashi, "Applicability of Extra-Local Methods for AssessingCommunity Resilience to Disasters: A Case of Sri Lanka," Journal of Environmental Assessment Policy and Management, 2016, vol. 18, no. 2, pp. 1-33.

13. P. Jayasinghe, N. Bandara, A. Jayasinghe, Y. Chemin and P. Mahanama, "Assess the Level of Vulnerability to Climate Induced Disasters in Sri Lankan Coastal Areas: An Application of Open Source Geographic Information System.," International Journal of Geoinformatics, 2015, vol. 11, no. 3, pp. 53-58.
14. Y. Wang, Y. Zou, K. Henrickson, Y. Wang, J. Tang and B.-J. Park, "Google Earth elevation data extraction and accuracy assessment for transportation applications," Plos One, 2017, vol. 12, no. 4, p. 1-26.

15. B. G. Dean, J. O. Michael and A. E. Gayla, "Accuracy Assessment of the U.S. Geological Survey National Elevation Dataset, and Comparison with Other Large-Area Elevation Datasets-SRTM and ASTER," U.S. Geological Survey, 2014.

16. L. A. Rossman, Storm Water Management Model - User's manual version 5.0, United States Environmental Protection Agency, 2010.

17. J. Xie, C. Wu, H. Li and G. Chen, "Study on Storm-Water Management of Grassed Swales and Permeable Pavement Based on SWMM," Water, 2017.

\section{AUTHOR PROFILES}

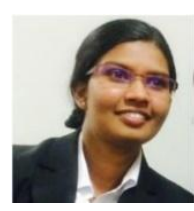

\section{Chethika Abenayake}

B.Sc.(Hons)(Town \& Country Planning), Sri Lanka; M.Plan.(Environment Planning), India, D.Eng.Japan; MITP(Sri Lanka), Chartered Town Planner.

Dr. Abenayake is working as a senior lecturer at Department of Town and Country Planning, University of Moratuwa, Katubedda, Sri Lanka. Her research works are focused on environmental planning, spatial planning, socio-ecological systems, disaster and resilience engineering.

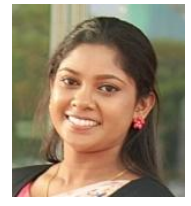

K. I. U. T. De Silva

B.Sc.(Hons)(Town \& Country Planning), Sri Lanka. Ms. De Silva is working at the Rainwater Harvesting Forum|, Sri Lanka. Her main research interests are environmental planning, rainwater harvesting, water management and GIS.

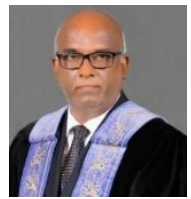

P. K. S. Mahanama

B.A.(Geography); M.Sc.(Town \& Country Planning); FITP(Sri Lanka), Chartered Town Planner.

Prof. Mahanama is the Deputy ViceChancellor (DVC) of University of Moratuwa, Katudedda, Sri Lanka. He is a leading urbanand environmental planner in Sri Lanka. His research works are focused on Urban-and regional planning, Sustainable development and GIS applications in Physical Planning. 